\begin{tabular}{l}
\hline Jurnal Scripta Teologi dan Pelayanan Kontekstual \\
ISSN 2086-5368 (Print) \\
ISSN \\
Http://ejournal.stte.ac.id \\
Vol.1, No.1, pp. 131-143, 2017
\end{tabular}

\title{
Pastoral Konseling Kristen Dalam Memurnikan Konsep Orang Tua Yang Menikahkan Anak Laki-Laki Di Bawah Umur 17 Tahun
}

\begin{tabular}{|c|c|}
\hline \multicolumn{2}{|r|}{$\begin{array}{l}\text { Kristina Herawati } \\
\text { STT Ebenhaezer Tanjung Enim, kristinasuharta@gmail.com }\end{array}$} \\
\hline INFO ARTIKEL & $\begin{array}{l}\text { ABSTRAK } \\
\text { Pernikahan adalah suatu ikatan lahir batin antara seorang pria dengan }\end{array}$ \\
\hline $\begin{array}{l}\text { Sejarah Artikel: } \\
\text { Diterima : } 04 \text { Okt } 2017 \\
\text { Direvisi : } 11 \text { Okt } 2017 \\
\text { Disetujui: } 18 \text { Okt } 2017 \\
\text { Dipublikasi: } 20 \text { Okt } \\
2017\end{array}$ & $\begin{array}{l}\text { seorang wanita sebagai suami istri dengan tujuan membentuk keluarga } \\
\text { (rumah tangga) bahagia dan kekal berdasarkan ketuhanan Yang Maha } \\
\text { Esa. Perkawinan adalah sah apabila dilakukan atas dasar agama, adat } \\
\text { istiadat dan undang-undang, oleh karena itu pernikahan merupakan } \\
\text { ikatan yang dilandasi pada moral etika dan agama, kedewasaan calon } \\
\text { suami- istri harus telah "masak jiwa raganya". Oleh karena itu, agar }\end{array}$ \\
\hline $\begin{array}{l}\text { Kata Kunci: } \\
\text { Pastoral, Konseling, } \\
\text { Kristen, Memurnikan, } \\
\text { Konsep, Menikahkan }\end{array}$ & $\begin{array}{l}\text { dapat mewujudkan tujuan pernikahan yang baik serta tercapainya } \\
\text { kehidupan keluarga yang harmonis, maka dibutuhkan kematangan baik } \\
\text { jasmani maupun spiritual bagi pasangan yang ingin melakukan } \\
\text { pernikahan. Tetapi dalam kenyataannya, masih ada terjadi pernikahan } \\
\text { dibawah usia. Di mana hal tersebut sangatlah beresiko bagi pernikahan }\end{array}$ \\
\hline $\begin{array}{l}\text { Keywords: } \\
\text { keyword one, keyword } \\
\text { two, keyword three. }\end{array}$ & $\begin{array}{l}\text { yang akan dijalani. Menyikapi fenomena tersebut, maka para pelayan } \\
\text { atau hamba Tuhan memiliki komitmen untuk menolong, mengarahkan, } \\
\text { membimbing, menopang dan menuntun supaya orang tua memahami } \\
\text { dasar pernikahan Kristen yang Alkitabiah. }\end{array}$ \\
\hline
\end{tabular}

\begin{abstract}
Marriage is a spiritual bond between a man and a woman as husband and wife with the aim of forming a happy and eternal family (household) based on the divinity of the Almighty. Marriage is legal if it is done on the basis of religion, customs and laws, therefore marriage is a bond based on moral ethics and religion, the maturity of a prospective husband and wife must have "cooked their body and soul". Therefore, in order to realize the goal of a good marriage and the achievement of a harmonious family life, it takes both physical and spiritual maturity for couples who want to get married.

But in reality, there is still underage marriage. Where it is very risky for the marriage that will be lived. Responding to this phenomenon, the servants or servants of God have a commitment to help, direct, guide, support and guide so that parents understand the basic Christian biblical marriage.
\end{abstract}

\section{Pendahuluan}


Dalam Undang-Undang No. 1 tahun 1974 tentang perkawinan dijelaskan bahwa perkawinan hanya diizinkan jika pihak pria sudah berusia 19 tahun dan pihak istri 16 tahun. Perkawinan harus didasarkan atas persetujuan kedua calon mempelai, maka untuk melangsungkan sebuah perkawinan seorang yang belum mencapai umur 21 (dua puluh satu tahun) harus mendapat izin kedua orang tua, dan apabila orang tua sudah meninggal atau dalam keadaan tidak mampu menyatakan kehendaknya maka izin diperoleh dari wali, orang yang memelihara atau keluarga yang mempunyai darah dalam garis keturunan, lurus ke atas selama mereka masih hidup dan dalam keadaan dapat menyatakan kehendaknya.

Dalam undang-undang pernikahan di kalangan Umat Kristen Protestan menjelaskan bahwa, seseorang yang mau menikah dituntut untuk mampu bertanggung jawab dalam lingkungan bermasyarakat dan bernegara. Karena itu perkawinan membutuhkan persiapan yang matang baik secara jasmani dan spiritual, agar suami istri sanggup membina rumah tangga yang harmonis dan menjadi saksi di tengah-tengah lingkungan sebagai Umat Kristen. Perkawinan di bawah umur 17 tahun menurut Undang-Undang dikalangan Umat Kristen Protestan kurang efisien, sebab mereka belum mampu meletakkan dasar yang kokoh untuk membina rumah tangga yang berisikan cinta abadi. Proses pacaran merupakan pengalaman yang penting dalam kehidupan pria dan wanita. Dimana proses pacaran bisa memiliki dampak yang besar dalam hubungan pernikahan pada masa yang akan datang dengan tujuan supaya pasangan yang mau menikah saling mengenal dengan yang lainnya, saling mengasihi serta saling memahami.

Dalam keluarga Kristen juga menjelaskan bahwa "jikalau bukan Tuhan yang membangun rumah, sia-sialah usaha orang yang membangunnya" konteks ayat ini berkaitan dengan pembangunan rumah tangga dimana Tuhan sendiri sebagai arsitek tunggal yang membangun rumah tangga umat-Nya (Maz. 127). Hal ini sangat jelas bahwa peranan Tuhan pertama dalam mempertemukan seorang laki-laki dan seorang perempuan melalui persahabatan, menentukan hubungan pacaran dan meningkatkan ke acara pertunangan, dengan maksud untuk lebih bertanggung jawab dan saling mengenal satu dengan lainnya. Kedua berbicara tentang peranan Tuhan dalam meningkatkan tali pernikahan dan dalam memelihara keluarga itu senantiasa. Tali pernikahan ini tidak boleh diputuskan oleh siapa pun dan apapun, karena apa yang telah diikat atau dipersatukan oleh Tuhan tidak boleh diputuskan/diceraikan oleh manusia (Mat. 19:6). Oleh sebab itu, kita harus menikah dengan orang yang tepat, karena pernikahan keluarga Kristen berdasarkan pada Tuhan sendiri, dimana la yang memulai inisiatif untuk menentukan dan mentahbiskan pernikahan menjadi suatu lembaga ilahi.

Dalam Kej. 1: 27-28; 2:19, 21-25 juga melaporkan hal yang sama bahwa Allah bertindak secara aktif merancangkan dan mempersatukan manusia, yakni laki-laki dan perempuan dan memberkati mereka menjadi sebuah keluarga. Keluarga yang telah dirancang dan dibentuk oleh Allah itu tidak akan lepas dalam kontrol Allah. Dia membimbing dan mengarahkan keluarga tersebut untuk terus mempermuliakan nama-Nya. Alkitab menyatakan bahwa Allah sendiri yang berinisiatif untuk menentukan dan mentahbiskan perkawinan menjadi satu lembaga ilahi. Allah sendiri yang menyediakan penolong yang sepadan bagi seseorang, untuk mengasihi dan saling melengkapi. 
Perkawinan adalah ciptaan Allah, Alkitab menjelaskan bahwa (tidak baik manusia itu hidup seorang diri saja, Aku akan menjadikan penolong baginya, yang sepadan dengan dia). Lalu Tuhan Allah membuat manusia itu tidur nyenyak, ketika ia tidur Tuhan Allah mengambil salah satu rusuk dari padanya lalu menutup tempat itu dengan daging. Dari rusuk yang diambil Tuhan Allah dari manusia itu, dibangunnyalah seorang perempuan (Kej. 2: 18, 21-22a). Marulak Pasaribu, dalam bukunya menuliskan:

Seorang penolong yang sepadan memiliki pengertian, seorang penolong yang sama kekhususannya atau seorang penolong yang layak berdiri dihadapan manusia sebagai temannya, pelengkapnya dan disini terkandung rasa inferioritas, rasa di bawah ukuran atau rasa diperuntukan sebagai budak melainkan seorang yang mirip dengan dia tetapi kebalikan dari dia.

Pengertian di atas menunjukkan bahwa Allah adalah pencipta perkawinan dan keluarga. Penyataan ini dapat dipahami bahwa Allah sangat peduli dengan keberadaan Adam pada saat itu, sehingga Allah bertindak menyediakan penolong baginya. Itu sebabnya bukan Adam yang merasa bahwa ia memerlukan jodoh melainkan Allah sendiri yang menjadikan Hawa, dengan mengambil tulang rusuk Adam. Dialah yang membawa Hawa kepada Adam.

Jadi, perkawinan merupakan suatu komitmen "bersatu" yang mempersatukan dua pribadi yakni antara seorang laki-laki dan seorang perempuan dalam satu hubungan kasih bersama, yang diteguhkan oleh Allah sendiri melalui hamba-Nya. Perkawinan itu bersifat seumur hidup. Dalam Kej. 2:24 Tuhan Allah berfirman sebab itu seorang laki-laki meninggalkan ayah dan ibunya dan bersatu dengan istrinya, keduanya menjadi satu daging. Masalah ini dipertegas lagi oleh Tuhan Yesus dalam Injil Mat. 19:6 "demikian mereka bukan lagi dua melainkan satu". Karena apa yang telah dipersatukan oleh Allah, tidak boleh diceraikan oleh manusia. Oleh karena itu, perkawinan merupakan suatu hubungan seumur hidup dan bersifat permanen. Dengan demikian, perkawinan merupakan suatu rancangan Allah, dimana Allah mempersatukan laki-laki dan perempuan dalam suatu ikatan perkawinan. Allah memiliki tujuan dalam perkawinan yaitu untuk mempermuliakan Allah.

Bagus Surjantono dalam bukunya "Membangun Keluarga untuk KemuliaanNya", mengatakan:

Keluarga Kristen tidak terjadi dengan sendirinya, tapi perlu curahan energi terbaik untuk membangunnya dalam anugerah Tuhan. Karena keluarga Kristen didesain dan diciptakan oleh Allah sendiri, maka tujuan keluarga Kristen adalah memuliakan Allah didalam Yesus Kristus.

Dalam keluarga Kristen Tuhan menghendaki supaya tidak terjadi perceraian, karena keluarga yang telah dirancang dan dibentuk oleh Allah itu tidak akan lepas dalam kontrol Allah. Dia membimbing dan mengarahkan keluarga tersebut untuk terus mempermuliakan nama-Nya.

Dewasa ini tujuan pernikahan sebagain besar sudah diselewengkan oleh manusia. Masih sebagian besar para orang tua yang melakukan pernikahan melalui perjodohan terhadap anak laki-laki di bawah umur, mereka lebih cenderung mengikuti tradisi adat dari pada mengikuti apa tujuan pernikahan Kristen. Orang tua tidak mengendalikan inisiatif Allah dalam merancang sebuah pernikahan. Orang tua lebih mengikuti keinginannya dari pada mengikuti peraturan yang telah ditetapkan oleh pemerintah dan agama. 
Ada berbagai alasan yang dikemukakan oleh pihak keluarga yang menikahkan anak laki-laki di bawah umur 17 tahun. Anak laki-laki terpaksa menikah di bawah umur dikarenakan perjodohan yang dilakukan oleh orang tua tanpa melalui proses pacaran, sehingga pernikahan itu tidak dilandasi dengan motivasi yang benar dan tidak sesuai dengan rancangan Allah. Banyak yang menikah karena terpaksa dengan motif membantu orang tua bekerja atau mencari nafkah, supaya orang tua cepat mendapatkan cucu, lepas tanggung jawab orang tua untuk menikahkan anaknya lakilaki, mengurus orang tua pada masa tua, orang tua merasa tenang atau senang kalau mereka melihat anak laki-lakinya sudah menikah selagi mereka masih hidup, suatu kebanggaan dan kehormatan dalam keluarga dan juga dalam lingkungan masyarakat. Oleh sebab itu, motivasi ini sangat berbahaya, baik dalam keluarga dan juga bagi lingkungan bahkan sangat bertentangan dengan pernikahan secara keluarga Kristen.

Oleh Karena itu, para pelayan atau hamba Tuhan memiliki komitmen yang sunggguh, dalam melayani Tuhan dan memiliki daya juang serta semangat untuk menolong, mengarahkan, membimbing, menopang dan menuntun supaya orang tua memahami dasar pernikahan Kristen yang Alkitabiah.

\section{Metode Penelitian}

Penelitian ini adalah penelitian kualitatif deskriptif yakni penelitian yang menggambarkan atau melukiskan objek peneliti-an berdasarkan fakta-fakta yang tampak atau sebagaimana adanya. Nawawi dan Martini (1996:73).

Teknik pengumpulan data dalam penelitian ini dilakukan dengan pengamatan atau partisipasi langsung dan penelaahan dokumen.

\section{Hasil Dan Pembahasan}

\section{A. Pengertian Pastoral Konseling}

Istilah "pastor" berasal dari kata dasar pastor atau gembala, dalam bahasa latin pastor. Dalam bahasa Yunani poimen. Oleh sebab itu, kata penggembalaan dapat disebut poimenika atau pastoralia. Dalam kata kerja yang berarti menuntun, memelihara ternak. Kata pastor dalam konotasi praktisnya ialah merawat atau memelihara. Gembala artinya penjaga atau pemelihara binatang, penjaga keselamatan orang banyak. Maka seorang gembala berusaha lelah, waspada, berani dan mau mempertaruhkan nyawanya sendiri untuk domba-dombanya. Kata gembala dalam Alkitab dipakai untuk menggambarkan tugas seorang hamba Tuhan dalam memelihara dan membimbing umat Tuhan sebagai kawanan domba Allah, sedangkan penggembalaan adalah suatu pelayanan yang mendampingi gembala untuk menguatkan dan mendoakan jemaat yang sedang dalam pergumulan.

Seorang teolog, Howard Clinebell mengatakan bahwa pastoral adalah suatu proses pertolongan berupa bimbingan kepada sesama yang mencakup pelayanan manusia secara utuh baik secara rohani dan jasmaniah. Dalam buku yang berjudul, Apakah penggembaan itu? Dijelaskan tentang tugas penggembalaan, yaitu:

1. Mencari dan mengunjungi anggota jemaat satu persatu.

2. Mengabarkan firman Allah kepada mereka yang sedang bergumul dalam pergumulan hidup yang berat.

3. Melayani mereka, artinya mereka ini perlu mendapat perhatian yang baik, tidak diabaikan dan tidak dilalaikan seperti domba-domba yang dikisahkan dalam (Yeh. 34). 
4. Supaya mereka lebih menyadari akan iman mereka, dan dapat mewujudkan, iman itu dalam hidupnya sehari-hari.

Jadi, dari beberapa pengertian di atas penulis menyimpulkan bahwa pastoral adalah pelayanan yang menyadarkan jemaat akan iman, jika jemaat kurang mengandalkan Tuhan, melalui pelayanan ini diharapkan mereka semakin bersandar dan mengandalkan Tuhan. Jika jemaat kurang setia, kurang taat dan malas mempraktikkan firman Tuhan, maka melalui pelayanan ini mereka didorong untuk mempraktikkan firman Tuhan dalam kehidupannya.

\section{B. Dasar Alkitabiah Pastoral Konseling Kristen}

Alkitab adalah firman Allah yang di dalamnya mengandung kebenaran dan kebenaran-kebenaran itu mutlak artinya tidak bisa diganggu gugat. Karena Alkitab berasal dari Allah sendiri dan tidak ada kesalahan di dalamnya. Oleh sebab itu, Alkitab merupakan standar final atau tolak ukur dalam pastoral konseling karena Alkitab memberikan petunjuk, arahan, tuntunan serta hikmat bagi konselor dalam melaksanakan pelayanannya. Dengan menjadikan Alkitab sebagai standar final dalam pelayanan pastoral konseling, maka konselor dapat membimbing konseli dalam menghadapi pergumulannya dalam terang firman Tuhan dan konseli dapat dibimbing untuk mengambil sikap hidup yang sesuai dengan kebenaran firman Tuhan. Bagian Alkitab yang sesuai akan membawa perubahan dalam diri seseorang, baik dalam Perjanjian Lama maupun dalam Perjanjian Baru.

\section{Perjanjian Lama}

Dalam Perjanjian Lama dasar Alkitabiah mengenai pastoral konseling terdapat dalam Yeh. 34, Maz. 23, dan Yes. 40:11. Di dalam penggembalaan sesungguhnya Tuhan adalah gembala yang sejati. Dasar utama penggembalaan adalah kasih. Gembala yang baik menuntun dan memelihara agar domba-domba itu dapat hidup bahagia seturut dengan firman-Nya, yang berdosa dipanggil untuk bertobat, yang tersesat dibawa pulang, yang hilang tidak dibiarkan, yang terluka di balut, yang sakit dikuatkan, yang gemuk di lindunginya. Tuhan adalah gembala yang baik bagi umat-Nya.

Daud mengakui bahwa Tuhan adalah gembalanya yang baik (Maz. 23), Tuhan menjaganya dalam berbagai pergumulan hidup, menuntun dan membimbingnya ke tempat yang tenang dan aman. Jadi, seorang gembala harus memperhatikan apa yang menjadi kebutuhan domba- domba gembalaanya, membuat mereka bahagia, menuntun kejalan yang benar dan melindungi mereka dari kesesatan. Gembala yang baik rela mempertaruhkan nyawanya untuk domba-dombanya.

\section{Perjanjian Baru}

Dasar pastoral konseling dari Perjanjian Baru, terambil dari Yoh. 10, Yesus tampil dalam empat karya. Pertama, la tampil sebagai guru. Tuhan Yesus mengajar dengan penuh wibawa dan kuasa. Kedua, Yesus tampil sebagai pembebas. Tuhan Yesus membebaskan manusia dari belenggu dosa. Yesus memerdekakan manusia dari dosa (Yoh. 8:36). Ketiga, Yesus tampil sebagai penyembuh. Keempat, Yesus tampil sebagai gembala. Yesus Kristus disebut Gembala Agung atau Gembala Sejati. Terbukti Yesus Kristus rela mengorbankan nyawa-Nya untuk domba-domba-Nya. Selain itu gembala yang baik mengenal satu persatu domba-domba-Nya (Yoh. 10: 3,14). Sikap gembala 
juga dituangkan dalam 1 Petrus 5, "gembalakanlah kawanan domba Allah yang ada padamu" artinya kegiatan pastoral konseling merupakan tugas penting yang harus dilaksanakan oleh para pemimpin jemaat dan konselor. Domba-domba yang ada tidak boleh dilalaikan, diabaikan apalagi sampai diterkam dan dicerai beraikan oleh roh-roh dunia serta ajaran-ajaran yang tidak benar. Tugas para pemimpin jemaat dan para konselor adalah membimbing, menuntun, mendampingi, dan menjaga agar dombadomba selalu ada dalam lingkungan domba lainnya.

Jadi, baik dalam Perjanjian Lama maupun dalam Perjanjian Baru, pelayanan pastoral konselling dipaparkan dengan jelas dimana Allah dan Tuhan Yesus Kristus berdiri sebagai konselor agung dan tugas ini juga dipercayakan kepada semua hambahamba Tuhan. Tuhan mau supaya jemaat yang dipercayakan dirawat dengan sungguhsungguh, yang lemah ditolong, yang sakit diobati, yang luka dibalut, yang hilang dicari dan yang sesat dibawa pulang.

\section{Prinsip Pastoral Konseling Kristen}

Kegiatan pastoral konseling yang efektif sangat penting untuk menolong orang yang sedang mengalami problema dalam hidupnya, konselor Kristen yang sungguhsungguh melayani, biasanya melalui pelayanan pastoral konseling, konselor lebih memahami apa masalah yang sedang dialami oleh konseli sehingga konselor bisa membimbing, menuntun, mengarahkan dan memberikan solusi yang baik kepada konseli. Pelayanan ini dilakukan hanya antara konselor dan konseli maksudnya bukan secara kelompok.

Jadi, pastoral konseling sangat penting dalam menolong orang tua khususnya orang tua di Kecamatan Susua Kabupaten Nias Selatan yang belum memahami dasar pernikahan keluarga Kristen. Sebagai hamba Tuhan harus bertangggung jawab untuk mengubah motivasi orang tua yang tidak benar melalui pelayanan pastoral konseling, supaya para orang tua di Kecamatan Susua Nias Selatan memahami tujuan pernikahan keluarga Kristen.

\section{Tugas dan Kepercayaan dari Allah}

Pastoral konseling adalah pelayanan hamba Tuhan yang dipercayakan oleh Allah sendiri. Dalam pelalayanan pastoral konseling menerima Alkitab sebagai standar dan otoritas tertinggi. Keunikan pastoral konseling juga terletak pada sikap hamba Tuhan yang percaya bahwa Alkitab adalah Firman Allah yang tertulis, standar kebenaran untuk menilai tingkah laku dan perbuatan adalah Alkitab. Konselor harus bersandar pada kuasa Roh Kudus dan Alkitab. Karena tidak dapat bersandar kepada pemikiran dan perasaan untuk mengarahkan sikap dan tingkah laku (Yoh. 6:63). Konselor percaya sepenuhnya bahwa Allah adalah satu-satunya kebenaran. Dan kebenaran itu dinyatakan melalui Alkitab.

Pastoral konseling tergantung sepenuhnya kepada kemampuan dan kuasa Roh Kudus. Keunikan pastoral konseling terletak pada sikap hamba Tuhan yang percaya akan kehadiran pengaruh dan campur tangan langsung dari Allah dalam pelayanan konselingnya. Karena itu, konselor dalam memecahkan masalah harus sungguhsungguh bergantung kepada kemampuan dan kehadiran Roh Kudus. Kahadiran Roh Kudus dalam pelayanan pastoral konseling sangat menolong konseli mengalami pengampunan dosa (I Kor. 6:20). 
Jadi, pastoral konseling merupakan tugas dan tanggung jawab hamba Tuhan untuk menolong, membimbing dan mengarahkan orang tua yang masih belum memahami tujuan pernikahan Kristen. Maka apabila pelayanan pastoral konseling dilakukan dengan sungguh-sungguh, maka akan berdampak mengubahkan pola pimikiran orang tua dalam memahami pernikahan keluarga Kristen yang benar.

\section{Firman Tuhan Adalah Dasar Pastoral Konseling}

Alkitab merupakan buku pedoman hidup Kristen yang utama dan mutlak mengandung kebenaran. Firman Allah yang tertulis yaitu Alkitab yang merupakan kesaksian tentang penyataan Allah yang pusatnya yaitu Tuhan Yesus Kristus. Karena itu firman Allah dengan Alkitab tidak dapat dipisahkan. Maka setiap orang yang percaya kepada Allah tidak bisa melakukan pastoral konseling tanpa di dasarkan pada Alkitab sebagai firman Tuhan.

Firman Tuhan yang tertulis dalam Alkitab merupakan tuntunan bagi seseorang, sebagai dasar pembimbingan yang utama membawa seseorang untuk semakin dekat kepada Tuhan. Alkitab memberi gambaran bagi keadaan manusia dan memberikan pengertian pada semua orang untuk dapat menghadapi semua masalah yang terjadi, masalah-masalah kehidupan tidak hanya terletak dalam jiwa, tetapi juga dalam roh. Semuanya ini tercakup dalam Alkitab yang menjadi satu-satunya kebenaran yang menjadi pegangan bagi setiap orang percaya.

Alkitab adalah firman Allah yang menjadi standar kebenaran yang diilhamkan Allah kepada manusia. Seperti 2 Tim. 3:16-17 berbunyi "segala tulisan yang diilhamkan Allah memang bermanfaaat untuk mengajar, untuk menyatakan kesalahan, untuk memperbaiki kelakuan dan mendidik orang dalam kebenaran. Dengan demikian tiaptiap manusia kepunyaan Allah diperlengkapi untuk perbuatan baik". Firman Allah yang penuh dengan pengetahuan, hikmat dan bimbingan bagi setiap orang melalui Roh Kudus. Dengan demikian Alkitab tidak ada bandingnya sudah sempurna dan secara khas mengikat. Konselor yang melakukan pelayanan pastoral konseling percaya bahwa Alkitab adalah kebenaran yang mutlak dan absolut.

Alkitab sangat layak jika dipakai menjadi dasar bagi setiap hamba Tuhan untuk melayani, membimbing dan mengarahkan orang tua yang menikahkan anak laki-laki di bawah umur 17 tahun di Kecamatan Susua Nias Selatan yang masih belum memiliki pemahaman tentang pernikahan keluarga Kristen. Sebab Alkitab adalah satu-satunya kebenaran Allah bagi dunia yang membutuhkan pertolongan.

Alkitab begitu jelas menekankan bahwa hanya satu Tuhan yang benar, serta memimpin dalam kebenaran yang menyelamatkan jiwa seseorang menuju pada hidup yang kekal. Allah yang benar mengetahui problema kehidupan yang ada di dunia serta menawarkan kepada dunia untuk terus berpengharapan kepada Allah yang benar itu, dengan demikian pengharapan di dalam Allah tidak akan mengecewakan.

\section{Pelayanan yang Mutlak Mengandalkan Kuasa Roh Kudus}

Roh Kudus adalah pembimbing orang Kristen. Peran Firman Tuhan dan Roh Kudus dalam proses pastoral konseling Kristen merupakan sentral dan terutama. Roh Kudus berperan sebagai penuntun, sedangkan Firman Allah memberi terang dan hikmat terhadap persoalan yang dihadapi serta memperoleh jalan penyelesaiannya. Roh Kudus adalah dinamika konseling Kristen. Dalam konseling Kristen, Roh Kudus menuntun konselor Kristen untuk melayani dan sekaligus memulihkan, mengubah 
serta mendewasakan konseli. Seorang konselor tidak dapat mengubah konseli, tetapi Roh Kuduslah yang dapat menuntun dan dapat mengubah hidup konseli, hal ini menunjukkan bahwa dalam pastoral konseling, seorang konselor menyadari sepenuhnya bahwa Roh Kudus juga hadir dalam pastoral konseling tersebut.

Roh Kudus menjadi sumber kekuatan dan hikmat baik bagi konselor maupun konseli dalam memahami permasalahan dan memecahkannya. Pekerjaan Roh Kudus adalah selaras dengan Firman Tuhan (Yoh.16:13). Salah satu yang membuat pelayanan Yesus berhasil yaitu dengan kuasa Roh Kudus (Luk. 3:21). William Crane dalam bukunya "Where God Comes In: The Divine Plus in counselling", membicarakan mengenai pelayanan Roh Kudus dalam hidup konselor dan konseli, yakni:

Roh Kudus mempunyai jalan keluar masuk ke dalam semua soal yang diketahui dan digunakan oleh para psikoterapi. Disamping itu, la memiliki jalan masuk langsung ke dalam pikiran dan perasaan yang paling dalam dari konselor. Jikalau konselor itu menjadi seorang konseli di hadapan hadirat Penasihat yang Ajaib itu dan sungguh-sungguh mencari teguran yang tulus, koreksi dan latihan dalam hal kebenaran yang Roh Kudus janjikan, mereka akan menemukannya. Banyak orang telah menemukannya.

Jadi, konselor Kristen yang melakukan pastoral konseling harus tetap mengandalkan kusa Roh Kudus. Ini berarti dalam pastoral konseling bagi konseli, dapat dikatakan sebenarnya Allah sendirilah yang menjadi konseor bagi konseli, sedangkan konselor hanya alat-Nya.

\section{Fungsi Pastoral Konseling Kristen}

Berikut ini penulis akan membahas tentang fungsi pelayanan pastoral konseling Kristen diantaranya: menyembuhkan, menopang, menuntun dan mendamaikan. Fungsi adalah kegunaan atau manfaat yang dapat diperoleh dari pekerjaan pendampingan tersebut. Dengan demikian, fungsi pendampingan merupakan tujuan-tujuan operasional yang hendak dicapai dalam memberikan pertolongan kepada orang lain.

\section{Menyembuhkan}

Tuhan memberi tugas tanggung jawab kepada hamba Tuhan untuk menyembuhkan konseli yang sedang mengalami problema dalam hidupnya. Penyembuhan hal yang sangat penting dilakukan oleh hamba Tuhan melalaui pastoral konseling kepada orang yang sedang mengalami problema, terluka hatinya, penyakit ini harus disembuhkan, supaya hidupnya menjadi baru dalam Kristus.

Fungsi menyembuhkan dalam pendampingan pastoral sangat penting karena melalui pendampingan konselor mengorbankan waktunya untuk memberi perhatiannya yang berisikan kasih sayang, rela mendengarkan segala keluhan batin dan kepedulian yang tinggi akan membuat seseorang yang sedang menderita, mengalami rasa aman dan kelegaan sebagai pintu masuk kearah penyembuhan yang sebenarnya. Menyembuhkan bertujuan untuk mengatasi beberapa kerusakan dengan cara mengembalikan seseorang kepada suatu keutuhan dan menuntun dia kearah yang lebih baik dari pada kondisi sebelumnya. Sebagai contoh dalam kisah orang Samaria yang murah hati, ketika ia membalut luka yang dirampok maka ia sedang melakukan fungsi menyembuhkan, ia menyiramnya dengan minyak dan anggur berarti ia melakukan menopang. Ketika ia menaikkan ke atas keledai dan membawanya ketempat penginapan, maka ia sedang melakukan fungsi menuntun (Luk. 10:33-34). 
Biasanya setiap orang yang mengalami pergumulan, terkadang mereka sulit mendapatkan cara menyelesaikannya. Maka sebagai konselor melakukan peranannya untuk berusaha menyelesaikan dan menyembuhkan konseli melalui pelayanan pastoral konseling. Menguatkan, menghibur dan menasihati mereka seperti halnya yang dialami oleh orang tua yang menikahkan anak laki-laki di bawah umur 17 tahun, masalah ini merupakan sebuah penyakit yang harus segera disembuhkan.

\section{Menuntun}

Istilah menuntun dalam Kamus Besar Bahasa Indonesia artinya membimbing atau menggandeng tangan, menunjuk dan mengarahkan ke jalan yang benar. Dalam hal ini seorang gembala membimbing, menggandeng, memimpin, mengarahkan, mengendalikan, mendidik, mengajar, mengasuh, domba-domba gembalaannya ke jalan yang benar. Dengan kata lain fungsi menuntun adalah pelayanan terhadap jiwa-jiwa dengan mempertimbangkan beberapa hikmat yang harus dilakukan oleh seseorang ketika ia diperhadapkan dengan kesulitan untuk memilih diantara bermacam-macam pemikiran dan tindakan. Karena itu konseli yang sedang menghadapi problema dalam hidupnya ia membutuhkan kawan yang menuntunnya. Maksud tuntunan itu ialah supaya konseli beroleh bantuan pastor melihat dan menyelesaikan masalahnnya.

\section{Mendamaikan}

Mendamaikan dari kata dasar "damai" artinya aman, tentram, tenang, rukun, keadaan tidak bermusuhan. Seseorang yang telah menyelesaikan masalah, kehidupannya baik terhadap sesama dan juga dihadapan Tuhan akan tentram dan aman karena hatinya telah dipenuhi damai sejahtera. Konselor bertanggung jawab untuk mengusahakan menyelesaikan masalah konseli dengan sesama dan kepada Tuhan agar kedua belah pihak berdamai kembali. Fungsi mendamaikan ialah berusaha memperbaiki relasi yang rusak antara manusia dengan Allah. Dengan kata lain mendamaikan merupakan fungsi tersendiri dari pelayanan pastoral.

Konseling pastoral merupakan suatu jawaban atas kebutuhan setiap orang untuk mendapatkan kesembuhan, topangan, bimbingan dan pendamaian dalam segala permasalahan hidup yang dialami oleh anggota jemaat. Kebutuhan akan pelayanan konseling pastoral ini dirasakan sangat penting dan pendesak pada saat terjadi krisis, kehidupan yang dialami oleh anggota jemaat, baik secara pribadi maupun dalam kehidupan sosial.

Dari beberapa fungsi pastoral konseling yang telah dipaparkan, penulis menyimpulkan bahwa pelayanan terhadap orang tua yang menikahkan anak laki-laki di bawah umur 17 tahun di Kecamatan Susua Kabupaten Nias Selatan, penting untuk dilakukan karena akan memulihkan kondisi orang tua tersebut seutuhnya. Maka orang tua tersebut mampu mengambil keputusan dan bertindak untuk menghadapi masalahnya dan orang tua mengalami pemulihan serta pendamaian hubungan dengan Allah, dirinya sendiri dan konselinya.

\section{E. Tujuan Pastoral Konseling Kristen}

Hamba Tuhan harus memiliki tujuan yang akan dicapai dalam pelayanan pastoral konseling diantaranya: menolong, membimbing, menyadarkan orang tua supaya memiliki pemahaman yang benar terhadap pernikahan Kristen. 


\section{Menolong orang Kristen Berpikir Secara Dewasa Tentang Pernikahan}

Istilah menolong dalam Kamus Besar Bahasa Indonesia artinya membantu untuk meringankan beban, penderitaan dan kesukaran. Hamba Tuhan telah diberi tugas tanggung jawab yang besar oleh Tuhan, salah satunya untuk menolong sesama yang ada dalam penderitaan, kesukaran dan beban hidup. Namun demikian tujuan konseling Kristen tidak hanya membantu konseli untuk dapat menyelesaikan masalahnya pada saat pembimbingan tetapi tujuan pastoral konseling adalah menolong orang Kristen untuk mengalami penyembuhan dan pertumbuhan iman kepada Tuhan.

Oleh sebab itu, tujuan pastoral konseling adalah untuk menumbuhkan kedewasaan orang Kristen dengan menolong konseling memiliki kualitas kehidupan dalam Tuhan yang lebih efektif yaitu suatu relasi dengan Tuhan yang lebih dalam atau hidup yang menyenangkan Allah. Kedewasaan orang Kristen mencakup dua elemen yakni ketaatan langsung dalam situasi khusus dan pertumbuhan karakter jangka panjang. Konseling boleh bertumbuh yakni melalui dua kebenaran: menghadapi setiap persoalan dengan suatu sikap yang konsisten dengan Alkitab dan mengembangkan suatu sifat dalam diri konseli sesuai dengan sifat yang ada dalam Kristus.

\section{Membimbing Orang Kristen Supaya Memahami Konsep Pernikahan yang Benar}

Membimbing artinya memegang tangan untuk menuntun, memimpin, memberi petunjuk, memberi penjelasan lebih dulu. Membimbing adalah menolong orang-orang yang sedang ada dalam kebingungan dalam mengambil keputusan-keputusan yang pasti diantara serangkaian alternatif pikiran dan tindakan, ketika pilihan-pilihan itu dipandang sebagai keadaan yang mempengaruhi jiwa mereka pada masa sekarang dan yang akan datang.

Pembimbingan adalah pekerjaan Roh Kudus. Maka pembimbingan yang efektif tidak dapat dilakukan tanpa bimbingan Roh Kudus. Roh Kudus adalah sumber dari pada segala perubahan pribadi menuju kesucian. Fungsi membimbing penting dalam kegiatan menolong dan mendampingi konseli. Maksud Pendampingan dalam konteks ini adalah konselor mendampingi konseli, ditolong untuk memilih atau mengambil keputusan tentang apa yang akan ditempuh atau apa yang menjadi masa depannya. Dalam pelaksanaan ini pihak yang paling bertanggung jawab adalah konseli, dengan maksud supaya konseli mau mengubah sikap, perilaku dan perbuatannya. Sedangkan konsele bertanggung jawab untuk mendampingi dan membimbing konseli. Konselor membimbing orang ke arah pemilihan yang berguna. Pembimbingan penggembalaan pastoral konseling membantu seseorang dalam mengatasi suatu konflik atau supaya ia dapat menyesuaikan diri terhadap hidup yang lebih baik.

\section{Membimbing Orang Kristen Untuk Dapat Mencari Kehendak Allah Tentang Konsep Pernikahan yang Benar}

Setiap orang yang sedang dalam problema, pasti ingin diperhatikan karena dia tidak tahu cara menyelesaikan masalah yang menghimpit hidupnya. Pada saat seperti inilah konseli memerlukan seseorang yang mampu menolong, membimbing, menuntun, mengarahkannya untuk menemukan jalan keluar dalam masalah yang sedang dia hadapi. Dalam hal ini orang yang tepat menolongnya adalah hamba Tuhan, karena hamba Tuhan orang yang telah dipilih Allah untuk menolong konseli menyelesaikan masalahnya. Pelayanan yang tepat untuk menyelesaikan masalah 
tersebut adalah melalui pelayanan pastoral konseling karena pelayanan tersebut bertujuan untuk menolong, membimbing dan mengarahkan konseli untuk menyelesaikan masalahnya. Dalam buku yang berjudul koseling psikoterapi mengatakan bahwa pembimbingan dari seorang konselor itu sangat perlu supaya konseli mengalami perubahan demi perubahan dalam hidupnya. Oleh sebab itu, sebagai seorang konselor yang telah diperlengkapi dan dipilih oleh Tuhan, harus melakukan tugas dan tanggung jawabnya dihadapan Tuhan dengan sepenuh hati agar konseli mampu menghadapi masalah yang sedang dia alami.

Konselor yang melakukan pelayanan pastoral konseling, perlu memfokuskan perhatian pada pembicaraan konseli, mendengarkan apa yang konseli sampaikan dan merasakan apa yang ia rasakan. Sehingga dengan cara tersebut konseli dapat mencurahkan isi hatinya terhadap masalah yang sedang dia hadapi, biasanya konselor yang melakukan cara tersebut dia mudah mengerti dan memahami apa yang menjadi pokok masalah yang sedang terjadi pada diri konseli dan kemudian menolongnya melalui pembimbingan. Maka dengan melakukan pembimbingan, konseli dapat menjadi percaya diri untuk menjalani kehidupannya.

\section{Memberi Pemahaman Bahwa Pernikahan Adalah Mandat Allah}

Pernikahan Kristen merupakan lembaga ilahi, yang telah dirancang dan dibentuk Allah sendiri. Firman Tuhan dalam Kej. 1: 27-28; 2:19, 21-25 menjelaskan bahwa Allah bertindak secara aktif merancang dan mempersatukan manusia yakni laki-laki dan perempuan dan memberkati mereka menjadi sebuah keluarga. Allah sendiri yang menyediakan penolong yang sepadan bagi seseorang, untuk mengasihi dan saling memperlengkapi.

Alkitab berkata bahwa maka Allah menciptakan manusia itu menurut gambarNya, menurut gambar Allah diciptakan-Nya dia laki-laki dan perempuan diciptakan-Nya mereka, lalu Allah berfirman kepada mereka "Beranakcuculah dan bertambah banyak penuhilah bumi dan taklukkanlah itu, berkuasalah atas ikan-iakan di laut dan burungburung di udara dan atas segala binatang yang merayap di bumi. Dalam Kej. 1:27-28 menjelaskan bahwa, Allah sendirilah yang menciptakan pernikahan melalui penciptaan seorang laki-laki dan seorang perempuan. Allah melihat bahwa tidak baik kalau manusia itu seorang diri saja Aku akan menjadikan penolong baginya yang sepadan dengan dia Kej. 2:18 artinya Allah pencipta pernikahan dan keluarga dengan tujuan untuk memuliakan nama-Nya. Inilah yang menjadi tujuan pastoral konseling yaitu membimbing orang Kristen yang melakukan perjodohan supaya mereka memahami bahwa pernikahan inisiatif Allah. Ketika orang tua telah memahami betapa pentingnya pernikahan Kristen secara Alkitab, maka orang tua memiliki motivasi yang benar dan melakukan perintah Allah dalam pernikahan dengan tidak melakukan pernikahan melalui perjodohan.

\section{Kesimpulan}

Hamba Tuhan dipanggil untuk melayani, salah satu dari pelayanan tersebut adalah pelayanan pastoral konseling. Pelayanan pastoral konseling merupakan pelayanan yang sangat penting dilakukan oleh gembala maupun semua hamba Tuhan. Karena begitu banyak masalah, pergumulan, persoalan yang dihadapi oleh orang percaya, maka hamba Tuhan dipercayakan Tuhan untuk bertanggung jawab menolong dan menyadarkan orang yang sedang mengalami problema dalam hidupnya. 


\section{Kepustakaan}

Abdurrahman \& Riduan Syahrani

1978 Masalah-masalah Hukum Perkawinan Di Indonesia, Bandung: Alumni,

Abineno, Ch.

1994 Sekitar Etika Soal-soal Etis, Jakarta: BPK Gunung Mulia

Abineno, J.L. Ch.

2011 Pedoman Praktis Untuk Pelayanan Pastoral Konseling, Jakarta: BPK

Ali, Lukman

1991 Gunung Mulia

arney, Kennet

1977

Beek, Aart Van 2001

Clinebell, Howard 2002

Kamus Besar Bahasa Indonesia Edisi Kedua, Jakarta: Balai Pustaka

Rumah Tangga Kristen, Malang: Gandum Mas,

Pendampingan Pastoral, Jakarta: BPK Gunung Mulia

Tipe-tipe Dasar Pendampingan dan Konseling Pastoral, Jakarta: Kanisius, BPK Gunung Mulia

Coon, Joyce Isaac dan Margaret Simbiri

1978 Rencana Allah Bagi Keluarga Kristen, Bandung: Yayasan Kalam Hidup

Crabb, Larry

1995

Konseling Yang Efektif dan Alkitabiah, Michigan: Zondervan Publishing

Susanto, Daniel

2003

Konseling Pastoral, Materi Kuliah Master Of Art in Pastoral

Gintings, E. P. 2009 Konseling Pastoral, Bandung: Bina Media Informasi,

Gunarsa, Singgih D.

Counseling, Batu: Institut Injili Indonesia

$1992 \quad$ Konseling dan Psikoterapi, Jakarta: BPK Gunung Mulia

Huwae, Carolis \& Rainer Scheunemann

2010 Metode Pelayanan Konseling Pastoral, Papua: Sekolah Alkitab Malam

Jay E. Adams 1986

Anda Pun Boleh Membimbing, Malang: Gandum Mas

Lukman, Titus

1998

Diktat: Keluarga Kristen, Tanjung Enim: STTE

Lukman,Titus

$1998 \quad$ Keluarga Kristen, Tanjung Enim: STTE

MacArthur, John F. Jr. Wayne A. Mack

1994 Pengantar Konseling Alkitabiah, Malang: Gandum Mas,

Martin dan Deidre Bobgan

1985 Bimbingan Alkitabiah Berdasarkan Firman Allah, Bandung: Yayasan

Kalam Hidup 
Niftrik, G. C. Van B. J. Boland

2001

Dogmatika Masa Kini, Jakarta: BPK Gunung Mulia

Poerwadarminta, W.J.S

1976 Kamus Umum Bahasa Indonesia, Jakarta: Balai Pustaka,

Powlison, David

2011

Mengatakan Kebenaran Dalam Kasih, Surabaya: Momentum,

Prince, Derek

1992

Pernikahan Ikatan yang Kudus, Jakarta: Imanuel

Ronda, Daniel

2015

Pengantar Konseling Pastoral, Bandung: Kalam Hidup

Storm, M. Bons

1998

Apakah Penggembalaan itu?, Jakarta: BPK Gunung Mulia

Sudibyo, Bambang

2008

Kamus Besar Bahasa Indonesia, Jakarta: PT Gramedia Pustaka Utama

Sugono Dendy 2008

Kamus Besar Bahasa Indonesia, Jakarta: PT Gramedia

Surjantoro, Bagus

2001

Membangun Keluarga Untuk Kemuliaan-Nya, Jakarta: BPK Gunung Mulia

Tu'u, Tulus

2007 Dasar-dasar Konseling Pastoral, Yogyakarta: Andi

Weinata Sairin \& J.M Pattiasina

1996 Pelaksanaan Undang-undang Perkawinan Dalam Perspektif Kristen, Jakarta: BPK Gunung Mulia

Wright, H. Normalan

1985

Konseling Krisis, Malang: Gandum Mas 